\title{
Natural Resources Investment of Oil and Gas and Regional Devel- opment Impact on Community Empowerment
}

\author{
Ridwan Nyak Baik
}

Received: 27032015 / Accepted: 2604 2015 / Published online: 30062015

(๑) 2015 Faculty of Geography UGM and The Indonesian Geographers Association

\begin{abstract}
This study was done in Bekasi district, at West Java, Indonesia, with the aims to analyze the management of upstream activities (exploration and production) of oil and gas industry and its impact on improving the quality of infrastructure, the equal benefits proportion for the corporation, local government and society, and CSR programs that would affect the community empowerment. The analysis would be calculated based on the per capita income, the number of medical personals, and the number of teachers. Based on that calculation, this study analyzed the impact of oil and gas activities to the regional development of the area under this study. Analysis of regional development was calculated through number of industry in the area, the economic growth, and local government revenue that affects community empowerment in Bekasi.Analyzed by structural equation modeling (SEM), the results showed that: (1) management of upstream oil and gas activities in this area have a positive influence, but no significant effect on community empowerment; (2) management of upstream oil and gas activities have a significant positive impact on regional development; (3) regional development has a significant positive impact on community empowerment; (4) management of upstream oil and gas activities have a greater positive influence towards community empowerment through regional development, because of the multiplier effect of the development of the region.
\end{abstract}

Keywords: management of upstream oil and gas activities, regional development, community empowerment, community development.munity development.

\begin{abstract}
Abstrak Penelitian ini dilakukan di Kabupaten Bekasi, di Jawa Barat, Indonesia, dengan tujuan untuk menganalisis pengelolaan kegiatan hulu (eksplorasi dan produksi) pada industri minyak dan gas beserta dampaknya terhadap peningkatan kualitas infrastruktur, proporsi keseimbangan manfaat untuk korporasi, pemerintah daerah dan masyarakat, dan program CSR yang akan mempengaruhi pemberdayaan masyarakat. Analisis akan dihitung berdasarkan pendapatan per kapita, jumlah tenaga medis, dan jumlah guru. Berdasarkan perhitungan, penelitian ini menganalisis dampak kegiatan minyak dan gas untuk pembangunan daerah yang diteliti. Analisis pembangunan daerah dihitung melalui jumlah industri di daerah, pertumbuhan ekonomi, dan pendapatan pemerintah daerah yang mempengaruhi pemberdayaan masyarakat di Bekasi. Metode analisis penelitian ini menggunakan Structural Equation Modeling (SEM), berdasarkan hasil penelitian menunjukkan bahwa: (1) pengelolaan kegiatan hulu migas di daerah ini memiliki pengaruh yang positif, namun tidak berpengaruh signifikan terhadap pemberdayaan masyarakat; (2) pengelolaan kegiatan hulu migas memiliki dampak positif yang signifikan terhadap pembangunan daerah; (3) pembangunan daerah memiliki dampak positif yang signifikan terhadap pemberdayaan masyarakat; (4) pengelolaan kegiatan hulu migas memiliki pengaruh positif yang lebih besar terhadap pemberdayaan masyarakat melalui pembangunan daerah, karena efek multiplier dari pengembangan wilayah.
\end{abstract}

Kata kunci: pengelolaan kegiatan hulu minyak dan gas, pembangunan daerah, pemberdayaan masyarakat, pengembangan masyarakat.

\section{Introduction}

The development of natural resources has played a significant role in the expansion of many regional economies around the world. Despite this important role, research on the relationship between natural resources and regional development has been identified as a neglected area in economic geography study. In several studies, controversy regarding the role of natural resources play in the development process

Ridwan Nyak Baik

Program of Regional Planning, Sumatera Utara University, Medan, Indonesia

Email: agambaik2000@gmail.com has been noticed. Some studies have concluded that natural resources are an important catalyst that can expedite growth, while other studies have suggested that resources can impede development by creating an unhealthy economic dependence [Gunton 2003].

In the context of regional development, Martin and Sunley [1998] explained about the possibility of economic convergence and economic divergence in regional development. The first, rooted in neoclassical equilibrium economics, holds that, provided there are no major barriers to the operation of market forces, in an integrated national space economy there are 
strong pressures leading to the general convergence of regional incomes over time. Regional disparities are unlikely to be persistent, since such inequalities will set in motion self-correcting movements in prices, wages, capital, and labor, which impart a strong tendency toward regional convergence.

On the contrary, in the second scenario, there are no necessary reasons why regional growth and incomes should converge, even over the long run. In this case, regional divergence is more likely. Martin and Sunley [1998] elaborate that regional incomes will tend to diverge, because market forces, ifleft to their own devices, are spatially dis-equilibrating. Economies of scale and agglomeration lead to the cumulative concentration of capital, labor, and output in certain regions at the expense of others: uneven regional development is self-reinforcing rather than self-correcting.

Understanding the two economic possibilities in regional development, it would be beneficial to research the management of upstream oil and gas exploration and production activities in the spatial effect of the regional development. This research is especially important in seeing the possible contradictory effect of the role of natural resources in regional development. The dependency theorists argue that natural resources could impede development, and at the other side, comparative-advantage theorists argue that natural resources can expedite development [Gunton 2003].

According to Zen [2001] there are three important factors that must be considered in the area of regional development: natural resources, human resources, and technology. The three factors are known as the three pillars of regional development. As one of the pillars, natural resources will not bring any effect without the intervention of human resources. Similarly, the natural resources of oil and gas will not contribute to the regional development when it is not managed by an investment management that exploited the resources.

In this research, investment management that did the exploitation of natural resources of oil and gas was PT. Pertamina EP, a subsidiary of PT. Pertamina (Persero) in Bekasi. Pertamina exploration and production activities had affected the existing physical and spatial infrastructure in that area, such as doing the construction or improvement of the quality of roads, bridges, buildings, and various production facilities.

In addition to the activities of the exploration and production of oil and gas, the local economic activity is increasing due to the more dynamic mobility of community in that area.

This encourages empowerment measures which, in turn, is part of the efforts to improve the welfare of the community, especially those located in the vicinity of the drilling field. Gunton and Richards [1987] explained these trends on the basis of the distribution of costs and benefits of public policy among various interest groups. The interests supporting generous access to resources are comprised of a limited number of actors, such as the resource companies and local business that receive high per capita benefits from state subsidies.

There were direct effects of a resource boom impact, mainly on the non-resource traded goods sector. First, increased disposable income will be partly spent on non-traded goods, for example construction and services, causing prices in these sectors to rise and real wages in the non-traded goods sectors to rise. To restore equilibrium in the labor and non-traded goods market, the real exchange rate has to rise and real wages in the non-traded goods sector have to fall. This, in turn, reduces the competitiveness of the traded non-resource good sector, partially crowding it out (spending effect). Second, factor remuneration will increase in the booming natural resource sector and lure workers and capital away from other sectors (resource pull effect). The size of both effects is, thus, to a large extent, determined by the sector's laborintensity and ownership: the higher the labor-intensity and the greater the levels of domestic ownership, the more severe are the two effects [Leite and Weidman, 1999]. In the context of oil and gas, the second effect tends to be less relevant since the production process is not very labor- intensive and the domestic financing effects are generally limited [Leite and Weidman, 1999].

This study would seek the effect of that oil and gas exploration and production to the community empowerment in the regional development context. To measure the community empowerment that triggered by the exploitation of oil and gas activity in the Bekasi area, this research will use the numbers of local economic growth, locally-generated revenue, income per capita, the number of medical personnel, and the amount of educators who are either directly or indirectly interacting in various aspects of life in community.

On the basis of the above description this study would analyzed how far the role of natural resource management of upstream oil and gas activities have an impact on the growth of the local economy which will encourage the development of the region. Also, how did the efforts of corporation that exploit natural resources for empowerment and increasing social welfare in a sustainable manner.

For a vast country like Indonesia, which likely will follow the dependency theorists that argue natural resources could impede regional development, this study will help to explain the real effect of regional development based on natural resources, especially oil and gas, and its impact on community empowerment.

1. Do the oil and gas management activities by proxy of improving the quality of infrastructure, profit sharing, and CSR programs, affect the community empowerment by proxy of income per capita, the number of medical personnel, and the number of teachers in Bekasi?

2. Do the oil and gas management activities by proxy of improving the quality of infrastructure, profit sharing, and CSR programs; 
affect the regional development by proxy of the number of industries, economic growth, and locally-generated revenue in Bekasi? Would the regional development by proxy of the number of industries, local economic growth, and locally-generated revenue affected the community empowerment by proxy of income per capita, the number of medical personnel, and the number of teachers in Bekasi.

3. Do the oil and gas management activities by proxy of improving the quality of infrastructure, profit sharing, and CSR programs affect the community empowerment by proxy of income per capita, the number of medical personnel, and the number of teachers through the regional development by proxy of the number of industries, local economic growth, and locally-generated revenue in Bekasi?

The role of natural resources in economic development has been an area of ardent debate in economics. From earlier findings of secularly declining price to later evidence on higher price volatility, policymakers have been encouraged not to rely extensively on resource-based growth, and theorists have debated widely on the optimal stance of public policy in the face of abundant natural resources [Leite and Weidman, 1999].

Sachs and Warner [1995] have analyzed some 70 countries data to find a negative relationship between the ratio of natural resources exports and the rate of economicgrowth, even aftercontrollingforvariablessuch as initial per capita income, trade policy, and investment rate. Quantitatively, they had estimated that an increase of one standard deviation in natural resource intensity (on average, 16 percent of GNP) leads to a reduction of about one percent per year in economic growth.

The contraction in the traded goods sector following an increase in natural resource revenues is what frequently referred to as the Dutch disease. In reality, the adjustment process can be thought of as rational response of the economy although overall welfare loss, through a reduction in long-term growth, can occur if linkages between sectors, or more precisely the lack of positive externalities of the resource sector, are considered [Leite and Weidman, 1999].

Failed government's policies aimed at developing the Niger Delta region that rich with oil and gas resources left it one of the poorest regions of Nigeria [Amadi and Abdullah, 2012]. Even the adoption of corporate social responsibility (CSR) policies and corporate-community relations (CCR) strategies by oil companies has failed to reduce the incidence of violent conflict between the host communities and oil companies in the Niger Delta, Nigeria.

Still, regional economies with an abundant supply of easily accessible natural resources have a considerable advantage in the development process. Demand, capital, and entrepreneurship are supplied by external export markets for the oil and gas product, instead of being restricted by regional consumption and savings rates. Manufacturing linkages are developed by the economic logic of processing resources prior to export to reduce weight and transportation costs. Higher incomes are generated by the local value or economic rent generated by the resource. Rent is defined as the surplus income earned in natural resource development after compensating for all other factors of production. The regional economy expands through these spread effects to achieve the economies of scale necessary to diversify through import. Overtime, the regional economy can become decreasingly dependent on an oil and gas export base and growth can become self-sustaining [Gunton, 2003].

Clearly, oil and gas as regional resources is not available in every region, and consequently would bring significant economy effect to the region. Oil and gas is a hydrocarbon compound that is formed in the earth's crust. Oil and gas is non-renewable natural resources, and classifie as strategic minerals which became one of the major contributors of foreign exchange, and still is the main energy source for industrial raw materials, transportation, and households.

In the framework of the investment management on exploration and production of natural resources of oil and gas, the corporation had to build supporting infrastructure both roads and bridges to facilitate transportation of drilling equipment, and other production facilities like tanks, reservoirs, pipelines, and office buildings. With all of these activities it would indirectly encourage the growth of local economic activities, which in turn will spur the development of the region and community empowerment, especially those residing in the area of oil and gas exploration and production operations.

The concept of planning is to set a goal and choose the appropriate steps necessary to achieve that goal [Tarigan, 2010]. This brief definition is not considered limited resources, as human resources, capital, and technology, in addition to the strategic environment that is constantly changing. By considering the limiting factor, planning is one of the important elements of management, as an effort to establish the goals and objectives that can be achieved after knowing and analyzing current conditions, forecast the development of a variety of factors that are relevant and some non-controllable. Within the good estimation of the limiting factors, the planner could have measured steps to achieve that goal.

In the context of regional planning, the area can be seen as a space on the surface of the earth, with a boundary as far as humans are still able to reach them either vertically or horizontally. Region is often defined as a geographical entity that has a space in a certain place without being too concerned about the limits and conditions.

Michael Dunford (NA) from University of Sussex explained a region is essentially a part of the land surface 
of the earth. In the geographical literature regions are defined in three ways as, respectively, uniform, functional and administrative areas. Most useful for economic development purposes are functional areas which combine places characterized by strong degrees of interdependence and strong complementarities.

In Indonesia, Rustiadi, Saefulhakim, and Panuju [2009] define the region as a geographical unit with specific or particular boundaries where the components have a specific meaning in planning and management description of development resources. This definition does not mention specific restriction of the area of a region. Sirojuzilam and Mahali [2010] view the region as a group of adjacent areas and inhabited by a number of people in a certain territory or space. Briefly, the concept of space or territory is characterized by absolute location and areal distribution of certain features on the surface of the earth.

From that perspective, regional planning can be formulated as an attempt to determine and analyze the current conditions, forecast the various relevant non-controllable factors, estimating the limiting factors, to ensure goals and objectives are expected to be achieved, determine the location and sets the steps to achieve the goal, then following with a variety of activities to be implemented to achieve that goal.

The driving force in regional planning is the responsibility taken for the improvement of living and working conditions of the population. Thus, the main objectives and tasks are being related mainly to the development of local infrastructure.

As a big and very vast country, Indonesia has a big challenge in managing its regional planning. Not Indonesia's entire region has an equal economic growth because of different resources as infrastructure, natural resources, business activities, or traditional culture and norms. Most of the economic activities happen in the big cities that have more resources compared to the rural regions.

In Indonesia, this sort of thing is noteworthy, because after the social reform in 1998 there was a tendency that each region has the freedom to voice their opinions and their disapproval of the development efforts, which are partly based on the vested interests of some parties [Alif and Artsanti, 2009].

Bekasi district where oil and gas exploitation was done by Pertamina is quite a specific area because it is located not far from the state capital and crossed by the main toll highway that connects the important cities in Java. Nonetheless, the district still has a rural region that was relatively more backward where oil and gas exploration activities carried out.

Within this condition, regional development should always mirror as part of the overall undertaken development effort, with the aim to improve the welfare of the community. According to Zen [2001], regional development is an effort to empower people living in an area to exploit the natural resources around them by using relevant technology as needed to improve the quality of life of the people concerned. The main objective of the development of the region is an attempt to harmonize the various sectors and areas of development activities, so that the utilization of existing resources can be optimized to support the activities of community life in accordance with the goals and objectives of the development of the region. In addition, another purpose of the development of the region is increasing the capacity expansion of the area and region in order to increase the output of the region, as well as to enhance the welfare in the broadest sense. In brief, it should help to empower the community in the region.

As Emejulu and Shaw [2010] stated, an important role for community development in the coming period will be the creation of democratic spaces which foster real empowerment by bringing different types of people together to debate what the 'good society' is, what it might look like and how it might be achieved.

Based on that statement, it is very clear that empowerment is a complex issue. According to Zimmerman [2000], empowerment may be viewed on different levels: individual, organizational or community. These levels are closely linked. In empowered communities, empowered organizations exist, and an empowered organization is reliant on the empowerment levels of its members. The current study focuses on community empowerment.

Kasmel and Andersen [2011] explained, community empowerment is either as a process or as an outcome. Through the process of empowerment, communities are able to assume power to act effectively to change their lives and environment. The community empowerment process promotes the participation of people, organizations and communities for increased individual and community control, political efficacy, improved quality of life and social justice. The primary concept is to mobilize local communities to address their health and social needs and to work inter-sector to solve local problems. Despite the wide use of empowering strategies in health and social development interventions and by many researchers, there seems to be no consensus on agreed methods or universally accepted measurement tools to assist in the evaluation of the community empowerment process.

In this study, community empowerment will be measured through income per capita, availability of health personnel and total teachers in that area. All of these measurements are reflecting the most important empowerment in the rural area that are very common lack of economic revenue, have very low health services and low in education. By these proxies, this study could measure the effect of oil and gas investment and regional development in that region on community empowerment. Zikmund et al. [2013] state a concept is a generalized idea that represents something of meaning. The conceptual framework or constructs is a term used 
to refer to concepts measured with multiple variables. Within a conceptual framework an extrapolation of events that reflect the relationship between the theories of the studied variables would provide guidance to solve the problems and formulate research hypotheses related to variables or problems that exist in the study.

In line with discussion on literature review, oil and gas investment in exploration and production activities will bring many effects to the society and environment, and possibly would change the social-economics of the region. Unfortunately, this research has the limitation cannot study all of the variables that could bring some effects based on oil and gas investment.

As seen on the path diagram (Figure 1), oil and gas investment in Bekasi District would definitely make an intervention steps for conducting exploration and production of oil and gas. These activities of natural resources exploitation will change the landscape of the region through:

(1) the development and improvement of the quality of infrastructure, (2) the result of the exploitation of natural resources of oil and gas activity for the local area, and (3) CSR program as an obligation of each investment in the extractive industries.

The presence of natural resource exploitation of oil and gas activities in the area will encourage the development of the region which is characterized by the following aspects: (1) the acceleration of the growth of the local economy, (2) the addition of local revenue, and (3) an increase in industrial activity.

Both then will accelerate the steps of community empowerment and increased prosperity of the society which can be seen through the following aspects: (1) income per capita, (2) the number of health workers, and (3) the number of teachers in that region.

1. Oil and gas investment by proxy of the development and improvement of infrastructure quality, profit sharing, and implementation of CSR programs has positive influence on community empowerment by proxy of income per capita, the number of medical personnel, and the number of teachers in the area.

2. Oil and gas investment by proxy of the development and improvement of infrastructure quality, profit sharing, and implementation of CSR programs has positive influence on the development of the region by proxy of local economic growth, an increase of local revenue, and number of industrial activities.

3. The development of the region by proxy of local economic growth, an increase of local revenue, and number of industrial activities has positive influence on community empowerment by proxy of income per capita, the number of medical personnel, and the number of teachers in the area.

4. Oil and gas investment by proxy of the development and improvement of infrastructure quality, profit sharing, and implementation of CSR programs will bring bigger positive effect with a mediating variable regional development (by proxy of local economic growth, an increase of local revenue, and number of industrial activities) to community empowerment by proxy of income per capita, the number of medical personnel, and the number of teachers in the area.

\section{The Methods}

Based on the large number of drilling oil and gas wells that were found in five sub-districts of oil-producing region in Bekasi, this study was conducted in six villages that have a density of oil and gas wells more than five locations. Total population in this region is 39,867 inhabitants, and the total number of drilling wells is at 101 point locations. To determine the number of samples is done by using the Slovin formula [Tejada \& Punzalan, 2012], and have total 396 respondents (Table 1).

Through Structural Equation Model (SEM) (Figure 2) researcher can simultaneously estimate the multiple interrelated dependence relationships and also has the ability to show the unobserved concepts and relationships that exist in it, and making calculation of measurement errors in the estimation process.

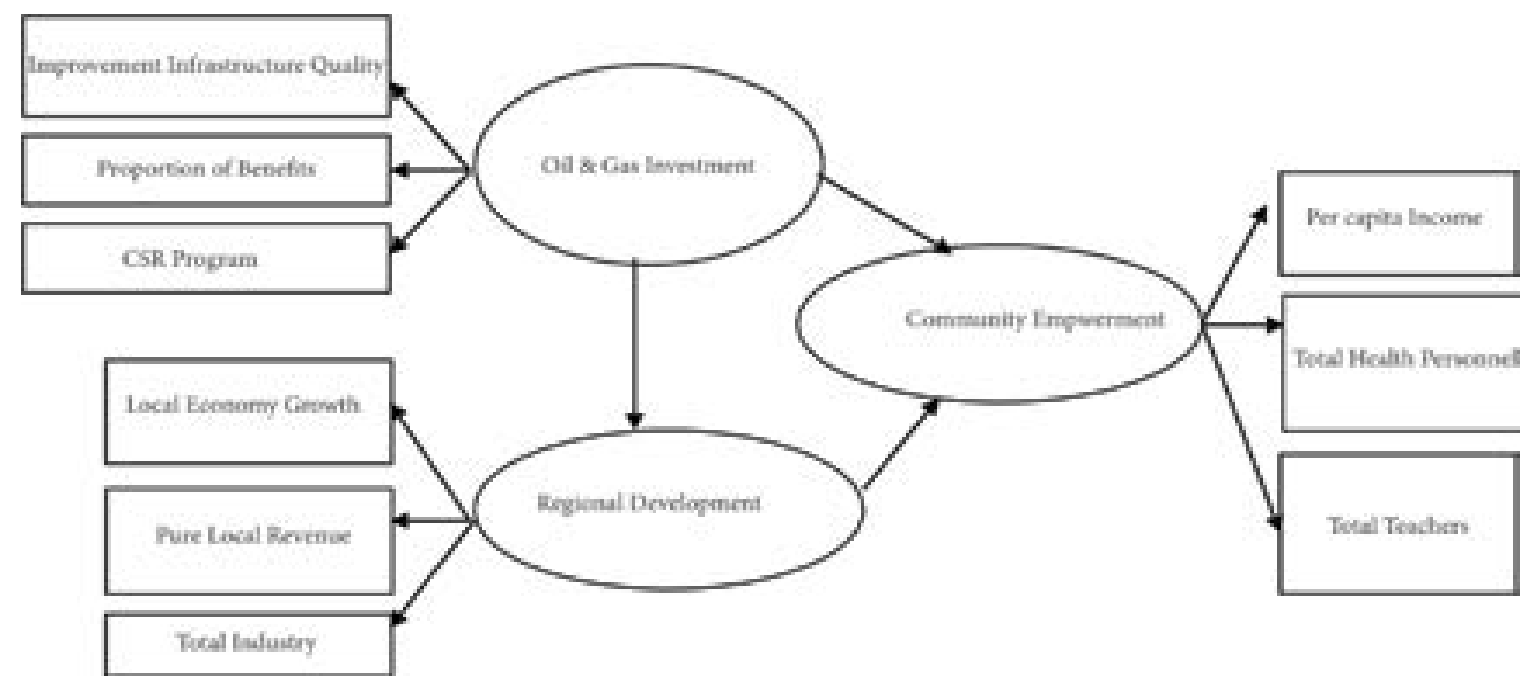

Figure 1. Research Conceptual Framework 


\section{Result and Discussion}

Of the total of 396 respondents who participated in study, most are male (69.7 percent). Average age of respondent is 45 years, mostly in the productive age range of $31-40$ years (29 percent) and $41-50$ years (23 percent). The rest is in the age bracket of 51-60 years (17 percent); $19-30$ years (16 percent); and more than 60 years (15 percent). Most of the respondents were working as farmers or land laborers (73 percent), then small scale vendors and traders (12 percent) and the rest working in public sector (15 percent).

Confirmatory Factor Analysis (CFA) was used to assess the relationship of independent variables with the others. Based on measurement model in SEM, the factor loadings for Oil and Gas Investment all are bigger that $0.50 \quad(\mathrm{X} 11=0.640 ; \mathrm{X} 12=0.812$; $\mathrm{X} 13=0.748)$. It is also same for factor loadings of Regional Development measurements (X21=0.747; $\mathrm{X} 22=0.702 ; \mathrm{X} 23=0.856) ;$ and for Community Empowerment $(\mathrm{X} 31=0.818 ; \mathrm{X} 32=0.847 ; \mathrm{X} 33=0.846)$.

The $\mathrm{t}$-statistic for all variable measurements are bigger than 1.96. The t-statistic result for Oil and Gas Investment are $\mathrm{X} 11=3.687 ; \mathrm{X} 12=13.770 ; \mathrm{X} 13=4.478$. It is also same for t-statistic of Regional Development measurements $(\mathrm{X} 21=6.710 ; \mathrm{X} 22=4.010 ; \mathrm{X} 23=20.507)$; and for Community Empowerment (X31=2.434;
$\mathrm{X} 32=19.321 ; \mathrm{X} 33=8.023)$. Based on the results of factor loadings and t-statistic of all of the indicators are valid to measure all of the variables in this study.

Reliability checks was done to get composite reliability for variable of Oil and Gas Investment (0.779); Regional Development (0.814); and Community Empowerment (0.652), all bigger than 0.6 [Fornell \& Larcker, 1981], as an indicator of reliable measurement.

The research model also shown a good fit with Goodness of Fit Index (GFI) 0.970 ( $\geq 0.90$ ); Adjusted of Goodness Fit Index (AGFI) $0.944(\geq$ 0.90); Normed Chi Square (CMIN/DF) 1.137 ( $\leq$ 2,00); Comparative Fit Index (CFI) 0.949 (>0.90); Normed Fit Index (NFI) 0.914 ( $>0.90)$; Incremental Fit Index (IFI) 0.950 (>0.90); and marginal fit for Relative Fit Index (RFI) 0.872; with Root Mean Square Error of Approximate (RMSEA) 0.056 ( $\leq$ 0,08).

Furthermore, based on the data processing of structural equation model using PLS Smart software the structural analysis is presented in the Figure 2.

As it was predict on hypothesis one, investment of oil and gas has a positive and significant impact on regional development (t-statistic $>1.96$ ). This result was supported by the facts on the ground, that the intervention of company oil and gas natural resources management is developing a positive effect in the

Table 1. Number of Sample Villages and Number of Respondents

\begin{tabular}{ll}
\hline Village/Sub District & Number of Respondent \\
\hline Bunibakti (Babelan) & 81 \\
Huripjaya (Babelan) & 35 \\
Kedungjaya (Babelan) & 99 \\
Samudrajaya (Tarumajaya) & 52 \\
Jayabakti (Cabangbungin) & 68 \\
Pantaiharapanjaya (Muaragembong) & 61 \\
TOTAL & 396 \\
\hline
\end{tabular}

[Source: Results of Research, 2013.]

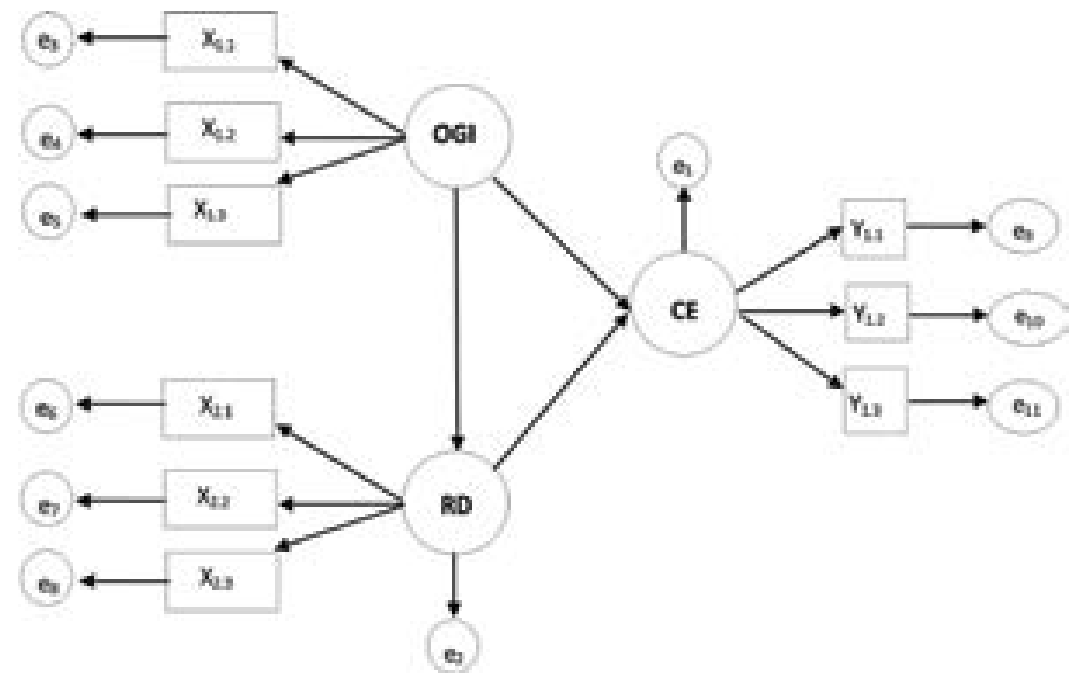

Figure 2. Structural Equation Model 
development of the region. As one of the important resources in Bekasi area, oil and gas exploration in that area made a significant improvement of infrastructure for the smooth operation of their activities. This is especially happen in the oil and gas producing districts such Babelan, Tarumajaya, Cabangbungin, and Muaragembong. The landscape in that area has changed as well as creates a more opportunity for the community.

This opportunity, in the fact, is triggered by accelerating the growth of the mobility of goods and people, as well as allowing the government, both at the district and county planning towards further development in order to more development in the region. Revenues from oil and gas exploitation of natural resources have also increased the revenue received by Bekasi District Government.

In Indonesia the revenue from natural resources is became the foundation for the district revenue. This revenue would be big enough to allow the execution of various development projects in that region. Although there is no nominal data for fund allocation from the oil and gas business that directly flow to the district producers, it is clear from the company activities in the sub-district area that the fund flows through CSR programs, the development and improvement of infrastructure, that all obtain benefits and welfare to the community.

The construction or improvement of infrastructure such as roads and bridges for the smooth operation of oil and gas exploitation has caused the multiplier effect growth in the economic activities in the region. Many shop-houses, housing estates, small and medium enterprises, café and restaurants, rice milling business, car washes and tire repair, mini market, and others business activities are exploding and encourage local economic growth.

Although the result was in line with the hypothesis two, oil and gas investment did not bring significant direct effect to community empowerment ( $\mathrm{t}$-statistic $<$ 1.96). This mean the company investment did not directly able to accelerate poverty reduction by developing self- reliance through community capacity building, and community-institutional participation in the implementation of development.

This result is relevant with the works of Idemudia and Ite [2006] that found community empowerment will be significantly improved if, and when, the needs and aspirations of the major stakeholders are addressed. In this case, community development activities are not a top-down intervention that does not uphold the aspirations and potential of the community to engage in self-help. As most of the society in the area, especially those living in the villages are in the lower class society, they need kind of empowerment through bottomup intervention. Then they would appreciate and recognizes their potential to meet their needs, solve their problems, and be able to carry out productive activities with the principle of self-help and togetherness.

That is the possibly explanation that the presence of oil and gas investment activities in the Sub

Table 2. Results of Structural Equation Model

\begin{tabular}{llll}
\hline Effect of & $\begin{array}{l}\text { Original Sample } \\
\text { Estimate }\end{array}$ & Standard Deviation & t- statistic \\
\hline $\begin{array}{l}\text { Oil \& Gas Investment - Regional De- } \\
\text { velopment }\end{array}$ & 0.510 & 0.081 & 6.303 \\
$\begin{array}{l}\text { Oil \& Gas Investment - Community } \\
\text { Empowerment }\end{array}$ & 0.136 & 0.173 & 0.790 \\
$\begin{array}{l}\text { Regional Development - Community } \\
\text { Empowerment }\end{array}$ & 0.356 & 0.168 & 2.122 \\
\hline
\end{tabular}

Figure 2. Structural Equation Model Results

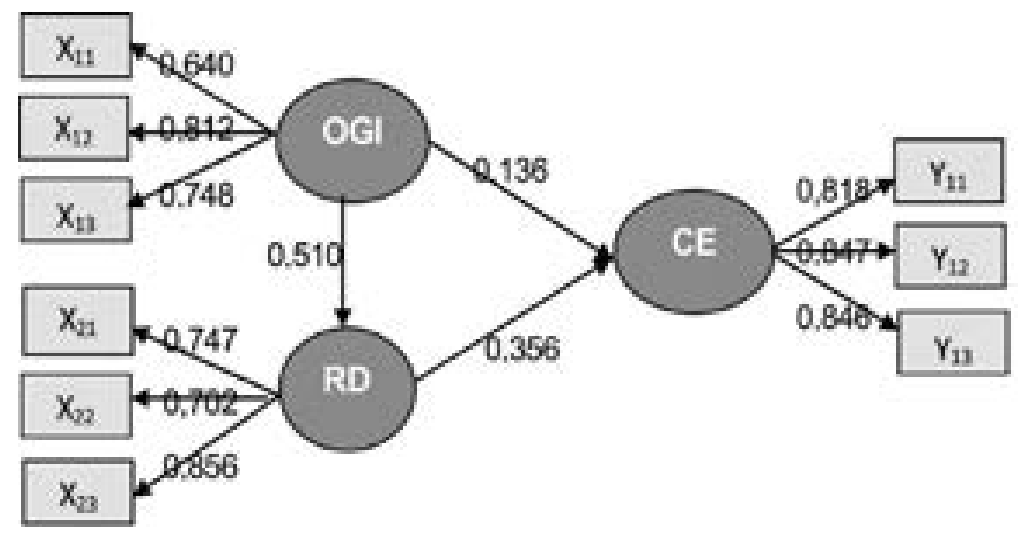


District of Babelan, Tarumajaya, Cabangbungin, and Muaragembong Bekasi Regency did not provide a significant direct impact on the surrounding community empowerment of oil and gas drilling locations.

The situation happens due to the nature of the oil and gas industry that are capital and technology intensive. Local human resources who did not have competences in the field of oil

and gas have not been able to directly take the initiative within the industry. They did not have a significant role in the dynamics of the spatial changes due to the presence of oil and gas industry in their area. Therefore the local community has not been able to appear as independent and resourceful subjects in a growing area for exploitation of natural resources of oil and gas. They are in many cases often become the object of potentially marginalized, when companies that exploit the natural resources of oil and gas in an area more concerned with the improvement of the efficiency and profitability of their exploration activities.

Based on statistical analysis, regional development has a significant and positive direct effect as stated on hypothesis three ( $\mathrm{t}$-statistic $>1.96$ ). This mean the local government should manage regional development carefully in their effort to empower the community.

Company exploitation in natural resources of oil and gas could influence the regional development through building and improving the quality of local infrastructure. This was done in order to speed up the transportation of various drilling and logistics equipment for the benefit of the project (Table 2).

On the other hand, the existence of such infrastructure has accelerated the growth of the business and production services. Several small and medium industries, as well as growth in other economic sectors has created new employment opportunities in the community that raised revenue for subdistrict area of Babelan, Tarumajaya, Cabangbungin, Muaragembong and overall Bekasi Regency in general.

Therefore, the presence of the government as spatial regulator, and as well as policy makers, should be in favor of empowering the community in the area. Through local governance strengthening and policies that open for wider participation, the community can develop their own identity from the object to become the subject of change and development.

As statistically analysis explained there was no significant direct effect of oil and gas investment to community empowerment. This study found that the oil and gas investment need a regional development variable as mediating effect to community empowerment. The combination of estimate effect through this mediating variable was shown the significant and positive impact of oil and gas investment to community empowerment. As discussed before it was encouraged by multiplying impacts caused by development of the region.

In investment for operations of oil and gas exploitation of natural resources, the company should build supporting infrastructure such as roads and bridges to facilitate transportation of drilling equipment, other production facilities and logistics. In addition, this infrastructure are also instrumental in opening wider access to the surrounding community for transportation of agricultural and aquaculture products to markets, or directly to consumers in the district of Babelan, Tarumajaya, Cabangbungin, Muaragembong, and also to anothers districts in Bekasi Regency. This has help encouraged the growth of community income and then help the welfare level to go up.

On the other hand, as an extractive corporation that exploit the natural resources in its operations, the company is required to help the local communities through programs of corporate social responsibility (CSR), as charity or on more sustainable empowerment activities. In order for the implementation of CSR programs on target, the company should develop CSR program that not overlap with other community development programs. In this case, an equitable local government as a stakeholder, regulatory, and development authority is very critical in providing judicious direction to help such programs to be success.

Therefore, the presence of oil and gas business investment in the region will be positive and bring significant impact on community empowerment, when the local government could wisely manage all of the stakeholders affected by the natural resources exploitation. The presence of the respected local government as policy makers and managers in the area of exploitation is very necessary for community to develop their identity of the object being an agent of change, and the subject of development.

\section{Conslusion}

1. Exploitation of natural resources of oil and gas as one of the important natural resource in the region directly provide a positive and significant impact on regional development.

2. The utilization of the natural resources of oil and gas as one of the important resource in the region have a positive impact, but not significant to community empowerment.

3. The development of the region are encouraged by the presence of oil and gas investment exploitation as one of the important resources in the District of Babelan, Tarumajaya, Cabangbungin, and Muaragembong has a positive and significant impact on community empowerment.

4. Exploitation of natural resources of oil and gas as one of the important resources in the region has a positive influence and a much greater effect towards communityempowerment through the development of the region when compared with its direct effect to community empowerment, because of the multiplier effect in the oil and gas exploitation.

5. The significant influence of oil and gas exploitation of natural resources as one of the important 
resources in Bekasi should have to be followed up through local government intervention programs both in terms of program planning in exploitation of oil and gas in that region, as well as from the perspective of Bekasi district development planning for the northern region where the exploitation was done. Therefore, there should be a necessary measurement to strengthen and increase the role of institutions and organizations, both in the sphere of society and government that would trigger the involvement of all stakeholders.

6. It is a need for a blueprint planning of the comprehensive and long term utilization of oil and gas exploitation so the development of the region with natural resources orientation can be done in an

\section{References}

Alif, M. Gunawan and Retno Artsanti [2009], Nutrition for Kids Was Good for the Company,International Corporate Responsibility Series 4:349-366.

Amadi, B. Obinna and Haslinda Abdullah (2012), Poverty Alleviation trough Corporate Social Responsibility in Niger Delta, Nigeria, Asian Social Science Vol. 8, No. 4, 57-68.

Dunford, M (NA) Area definition and classification and regional development finance: the European Union and China School of Social Sciences and Cultural Studies, University of Sussex, Falmer, Brighton BN1 9QN.

Emejulu, A. and Mae Shaw (2010), Community Empowerment: Critical Perspectives from Scotland, The Glasgow Papers, Edinburgh: Community Development Journal.

Fornell, Cloes and David G. Larcker (1981), Evaluating StructuralEquation Modelsand MeasurementError, Journal of Marketing Research, 18 (1 Feb.), p.39-50.

Gunton, T (2003), Resources and Regional. Development: An Assessment of Dependency and Comparative Advantage Paradigms, Economic Geography, Vol. 79, No. 1 (January), pp. 67-94.

Gunton, T. I., and J. Richards., eds. (1987). Resource rents and public policy in western Canada.Halifax, Nova Scotia: Institute for Research on Public Policy.

Idemudia, U. and Uwem E. Ite (2006), CorporateCommunity Relations in Nigeria's Oil Industry: Challenges and Imperatives, Corporate Social Responsibility and Environment Management. 13. 194-206.

Kasmel, A. and Pernille Tanggaard Andersen (2011), Measurement of Community Empowerment in Three Community Programs in Rapla (Estonia), International Journal of Environmental Research and Public Health, 8, 799-817. integrated manner. Thus, measures and policies related to community development in the districts and the surrounding oil and gas exploration such as Babelan, Tarumajaya, Cabangbungin, and Muaragembong can develop optimally in the synergy of its available resources.

7. The Corporate Social Resposibility (CSR) program of the company that producing oil and gas in the northern region of Bekasi to be planned sustainable with involving community participation in order to influence the improvement of the surrounding community empowerment and self-reliance. Therefore, social research needs to be done with the orientation of the operating activities of oil and gas resource management as one of the important resources in Bekasi.

Leite, C. and Jens Weidman (1999), Does. Mother Nature Corrupt? Natural Resources, Corruption, and Economic Growth, Working Paper of the International Monetary Fund. Martin, R. and Peter Sunley (1998), Slow Convergence? The New Endogenous Growth Theory and Regional Development, Economic Geography Vol. 74, No. 3 (July), pp. 201- 227.

Sachs, J. and A. Warner (1995), Natural Resource Abundance and Economic Growth. NBER Working Paper 5398, Cambridge, MA: National Bureau of Economic Research. Sirojuzilam and Mahali K, (2010), Regional, Pembangunan, Perencanaan, dan Ekonomi. USU Press, Medan.

Tarigan, R. (2010), Perencanaan Pembangunan Wilayah, Cetakan kelima, PT Bumi Aksara, Jakarta.

Tejada, J. J and Joyce Raymond B. Punzala (2012), On the Misuse of Slovin's Formula. The Philippine Statistician, Vol. 61, No. 1, p: 129-136, Univ. of the Philippines Diliman.

Zen, M.T. (2001), Core Philosophy in Regional Development: Empowering Human Being, Centre for Regional Development Technology Policy and Studies, BPPT Jakarta.

Zikmund, W.G., Barry J Babin, John C. Carr, and Mitch Griffin (2013), Business Research Methods, South-Western, Cengage Learning.

Zimmerman, M.A. (2000), Empowerment theory: Psychological, organizational and community levels of analysis. In Handbook of Community Psychology; Rappaport, J., Seidman, E., Eds.; Kluwer Academic/ Plenum Publishers: New York, NY, USA, pp. 43-63. 